\title{
Nanotechnológia a környezettudományban - nanorészecskék kölcsönhatása a környezettel
}

\author{
BÉLTEKY Péter ${ }^{\mathrm{a}}$, RÓNAVÁRI Andrea ${ }^{\mathrm{a}, \mathrm{b}}$ és KÓNYA Zoltán ${ }^{\mathrm{a}, \mathrm{c},{ }^{*}}$ \\ ${ }^{a}$ SZTE TTIK, Alkalmazott és Környezeti Kémiai Tanszék, 6720 Szeged, Rerrich Béla tér 1. \\ ${ }^{b}$ SZTE TTIK, Biokémiai és Molekuláris Biológiai Tanszék, 6726 Szeged, Közép fasor 52. \\ ${ }^{c}$ MTA-SZTE Reakciókinetikai és Felületkémiai Kutatócsoport, 6720 Szeged, Rerrich Béla tér 1.
}

\section{Bevezetés}

A nanotechnológia napjaink egyik legjelentősebb kutatási ágazata, ami az ipari fejlesztések során is egyre nagyobb jelentőséggel bír; az évente elöállított nanoméretü anyagok mennyisége a kilotonnás nagyságrendbe tehető és becslések szerint globális értékük 2018 végére elérheti a 4,4 billió USD- $\mathrm{t}^{1,2}$. A különböző tulajdonságú nanoanyagok felhasz-nálása kiterjed az élet majdnem minden területére, az ipari beruházásoktól a gyógyászati megoldásokon át egészen a mindennapi használati tárgyainkig. A széleskörü alkalmazásukat figyelembe véve könnyen belátható, hogy ezen anyagok könnyen kikerülhetnek, és ki is kerülnek a környezetbe. Számos tanulmány egyetért abban ${ }^{3-8}$, hogy a környezetbe kikerülő, különböző jellemzőkkel rendelkező nanoanyagok kapcsán lehetségesen fellépő toxikus és környezetszennyező hatások miatt további, az előállításukhoz és felhasználásukhoz kapcsolódó átfogó kutatások, teljes életciklus analízisek szükségesek. Továbbá ezen felmérések eredményei alapján szabályozások válhatnak szükségessé. Azonban ezen vizsgálatok egyelőre nem megoldottak a lehetséges fellépö folyamatok nagyfokú összetettsége miatt. A környezeti hatások értelmezésének nehézsége elsősorban abban rejlik, hogy ezek túlnyomó része nemcsak a primer nanoanyagok közvetlen hatásainak tudhatók be, hanem a környezet és a nanoanyagok között kialakuló speciális határfelületen lejátszódó folyamatokat is figyelembe kell venni.

A probléma mélyebb tárgyalásához először tisztáznunk kell, mit is értünk környezet alatt; ebben az értekezésben környezet alatt a körülöttünk lévő természetet és az élő szervezeteket együttesen értjük, melyek állandó kölcsönhatásban vannak. Einsteint idézve: ,,a környezet az minden, ami nem én vagyok", ami esetünkben egy nagyon találó megközelítés, hiszen a nanoanyagok számos, és nagyon összetett kapcsolatokat képesek kialakítani megannyi a környezetben fellelhető vegyületcsoporttal. Csak néhány példát említve, ameddig bizonyos elektronikai és optikai felhasználások esetén a változásokat ténylegesen a felhasznált nanorészecskék natív képességeinek tulajdoníthatjuk, addig a katalitikus és biológiai folyamatok kapcsán a részecske-határfelületen végbemenő változások minden esetben meghatározóak.
A méretcsökkenésnek köszönhetően kialakuló kristályrácshibák és a szintézisekből visszamaradó szennyeződések képesek katalitikus és oxidációs-redukciós (redoxi) folyamatok aktív helyeként funkcionálni (1. ábra). Az így keletkező szabadgyökök olyan láncreakciókhoz vezethetnek, amik nagymértékben hozzájárulnak az oxidatív stresszhez, ezzel nagy károkat okozva a környezet minden szintjén4. Folyadékokban, bizonyos esetekben a nanorészecskéket felépítő atomok vagy molekulák képesek beleoldódni a közegbe; az ezüst nanorészecskék egyik legelterjedtebben elfogadott hatásmechanizmusa például a felületről felszabaduló és hatásukat kifejtő ezüst ionokon alapul $^{9}$.

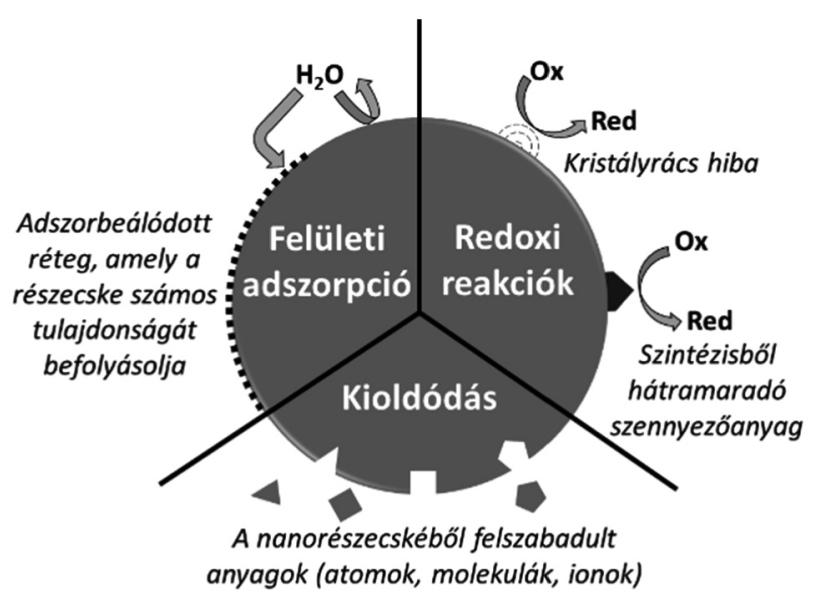

1. Ábra A nanoanyagok környezettel történő kölcsönhatásainak főbb mechanizmusai (felületi adszorpció, redoxi folyamatok és kioldódás).

Környezeti szempontból viszont a részecskefelületen lejátszódó adszorpciós folyamatok bírnak talán a legnagyobb jelentőséggel, hiszen mindamellett, hogy meghatározzák a nanoanyagok kolloidális stabilitását, aggregációs viselkedésüket, vagy akár reakciókészségüket is ${ }^{4,10}$, az adszorbeálódó biomolekulák azt is nagymértékben befolyásolják, hogy a környezet hogyan viselkedik a nanoméretü objektumokkal szemben. A következőkben ezeknek a folyamatoknak a jelentőségét szeretnénk bemutatni. 


\section{Nanorészecskék az élő szervezetekben}

A nanomedicina a nanotechnológia humán gyógyászatban történő felhasználását jelenti, ami egyre nagyobb teret hódít a tudományos kutatásokban ${ }^{11-13}$. Ez az új terápiai ágazat egy napon képes lehet eddig gyógyíthatatlan betegségek diagnosztikájára és kezelésére új hatóanyagok és célzott gyógyszerszállító-eszközök létrehozásával ${ }^{14}$. Az élö szervezetek fluidumaiban jelenlévő bio-molekulananorészecske kölcsönhatások viszont egy újfajta szemléletmódot igényelnek a hagyományos farmakokinetikai megközelítésekhez képest ${ }^{15}$.

Az a megfigyelés, amely szerint a szervezet fehérjéi képesek ráadszorbeálódni a nanorészecskék felszínére nem új keletü. A témához kapcsolódó első megfigyelések az 50-es, 60-as években jelentek meg ${ }^{16,17}$. Ezek a kutatások fóként gélelektroforézist felhasználó fehérje adszorpción alapuló vizsgálatok voltak és arra irányultak, hogy az intravénásan beadagolt nanorészecskék véráramban töltött keringési idejét meghosszabbítsák ${ }^{18}$. Az eredmények, habár a mai napig nagy jelentőséggel bírnak, nem mutattak túl a fehérjék adszorpciójának jelenségén, amit az opszonizációval analóg módon magyaráztak. Opszonizációnak nevezzük az immunrendszer azon stratégiáját, aminek során a szervezet úgynevezett opszonin molekulák (például antigének) segítségével megjelöli a patogén anyagokat a megfelelő karakterisztikus epitóp helyeken, ezáltal serkentve a makrofág sejteket, hogy az általuk megjelölt objektumokat kebelezzék be.

A 2000-es évek során ez az elképzelés a fehérje korona elméletté nőtte ki magát, főként a nagy áteresztőképességü tömegspektrometriai kutatásoknak köszönhetően ${ }^{18}$. A fehérje korona modell legjelentősebb és egyben legmegosztóbb megfigyelése a kemény (hard) és lágy (soft) koronák létezése volt. A szerkezetükkel kapcsolatban a legtöbb értekezés egyetértett abban, hogy a kemény korona az egy olyan kompakt képződmény, ami nagy affinitással kapcsolódó fehérjéket tartalmaz a nanorészecskék felületére adszorbeálódva, amíg a lágy korona egy lazább, nagyobb méretü és dinamikusan változó szerkezet, amiben a fehérje-fehérje kölcsönhatások sokkal nagyobb jelentőségűek, mint a kemény korona esetében, ahol a részecske-fehérje kapcsolatok dominálnak. Azonban a koronák közötti összefüggésekről az elméletek már nem voltak egységesek; egyes kutatások szerint a nanoanyagok biológiai közeggel történő érintkezésekor először lágy korona alakul ki, ami az idő elörehaladtával válik kemény koronává ${ }^{15}$, más szerzők szerint pedig ezek a mag-héj szerkezetként egymás mellett létező és megfelelő eszközökkel függetlenül vizsgálható rendszerek ${ }^{19}$.

A legfrissebb kutatási eredmények alapján napjainkban felismerték, hogy a koronák kialakulásában nem csak fehérjék, hanem egyéb biomolekulák (például lipidek, aminosavak, cukrok, hormonok és metabolitok) is aktívan részt vesznek, emiatt célszerü a pár évvel ezelőtti fehérje korona elnevezést biomolekuláris koronára módosítani $(2$. ábra $)^{18}$. Fontos megfigyelés továbbá az is, hogy a biomolekuláris koronák kialakulása egyfajta biológiai identitást kölcsönöz a szervezetbe kerülő nanorészecskéknek és ez a karakterisztikus tulajdonság az, ami eldönti, hogy a szervezet elsődlegesen milyen válaszreakciókkal reagál a megjelenésükre. A legújabb kutatások ezen kölcsönhatások molekuláris szintü megfigyelésére és megértésére irányulnak, kémiai és biológiai eszközöket egyaránt felhasználva.

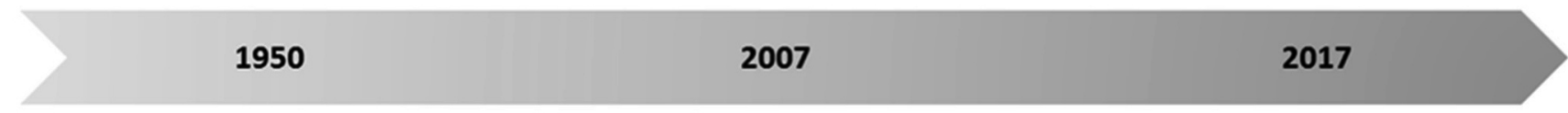

'Fehérje adszorpció'

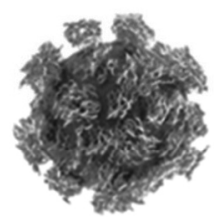

- Opszonizációval magyarázott modell

- Gélelektroforézises kutatások

- A nanoanyagok farmakológiájának megfigyelése

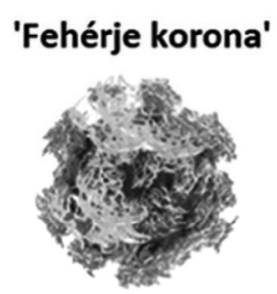

- Kemény és lágy korona modell

- Tömegspektroszkópiás kutatások

\section{- A nanoanyagok biológiai hatásainak kutatása}

'Biomolekuláris korona'

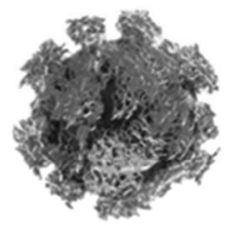

- Fehérjéken túlmutató, összetett modell

2. Ábra A nanorészecske korona elmélet fejlődése: a kezdeti, 60-as évekbeli fehérjék adszorpciójához kapcsolódó kutatásoktól a fehérje korona majd a legújabb biomolekuláris korona elmélet tanulmányozásáig. Felsorolva a kutatások fő céljai és eszközei ${ }^{18}$. 
A Szegedi Tudományegyetem Alkalmazott és Környezeti Kémiai Tanszékén az elmúlt években ezen érdekes kutatási témához kapcsolódóan vizsgáltuk különböző fém nanorészecskék élő szervezetekkel való kölcsönhatását. Munkánk céljául különböző zöld, környezetbarát redukálószerek segítségével ezüst nanorészecskék előállítását, valamint kémiai és biológiai rendszerekben való viselkedésük átfogó, összehasonlító tanulmányozását tüztük ki.

A kutatómunka során sikeresen állítottunk elő kávé és zöld tea kivonatával is nanoezüst részecskéket, amelyeknek elvégeztük komplex kémiai és biológiai vizsgálatát ${ }^{20}$. A kapott eredményeink alapján mindkét ezüst nanorészecske hatékonynak bizonyult a tesztelt mikrobák ellen, habár a zöld teával elöállított ezüst nanorészecskék (GT-AgNP) minden esetben jelentősen nagyobb toxikus hatást fejtettek ki a vizsgált baktérium és gomba törzsekre, mint a kávéval előállított ezüst nanorészecskék (C-AgNP). A szakirodalomban elfogadott ténnyel szemben, meglepö módon minden vizsgálatunk során azt tapasztaltuk, hogy a nagyobb részecskemérettel rendelkező GT-AgNP részecskék toxikusabbnak mutatkoztak a C-AgNP részecskékhez képest. Induktív csatolású plazma tömegspektrometriai méréseink alapján valószínüsítettük, hogy ez a jelenség annak köszönhetö, hogy a C-AgNP részecskéket körülvevő stabilizáló mátrix (biomolekuláris korona) miatt 3,5-ször kevesebb ezüstion tudott felszabadulni a C-AgNP részecskék felszínéről, és emiatt kisebb a C-AgNP nanorészecskék toxicitása. Mivel ezen nanorészecskék hatékonyan pusztították az összes tesztelt mikrobát, viszont az emlős sejtekre nézve biokompatibilisabbak, így további ígéretes felhasználásukat elősegítő vizsgálatok elvégzése mellett számos érv szól.
Hasonló megfigyeléseket tettünk Phaffia rhodozyma élesztőgomba segítségével előállított fém nanorészecskék esetében az élő szervezetek és nanorészecskék kölcsönhatásának tanulmányozása során. Közel azonos méretü és koncentrációjú ezüst nanorészecskék eltérő toxicitással rendelkeztek a kávé és zöld tea kivonatával készült ezüst nanorészecskékhez képest ugyanazon vizsgált élesztőgombákra ${ }^{21}$.

Az elvégzett kísérleteink eredményei alapján arra a következtetésre jutottunk, hogy az ezüst nanorészecskék előállítási módja és a részecskék felszínén kialakult biomolekuláris korona jellege jelentősen meghatározta a kapott nanorészecskék kémiai és biológia jellemzőit. A jövőben ezen nanorészecske-élő szervezet kapcsolatokról szerzett ismeretek orvosbiológiai hasznosítása nyújthat választ olyan problémák megoldására, mint például a célzott gyógyszeradagolás és diagnosztika ${ }^{18}$, ezért további ilyen jellegü kutatások megvalósítása mellett számottevő érvek sorakoznak.

\section{Nanorészecskék a természetben}

A nanorészecskék kiterjedt ipari, mezőgazdasági és lakossági felhasználásaik miatt számos módon kikerülhetnek a természetbe. Közvetlenül felhasználják öket például a kármentesítési munkálatok során, de indirekt módon is kijuthatnak a gyártás, szállítás, tárolás és felhasználás közben vagy akár a nanoanyagokat tartalmazó fogyasztói termékek hulladékként történő elhelyezésekor is ${ }^{22,23}$.

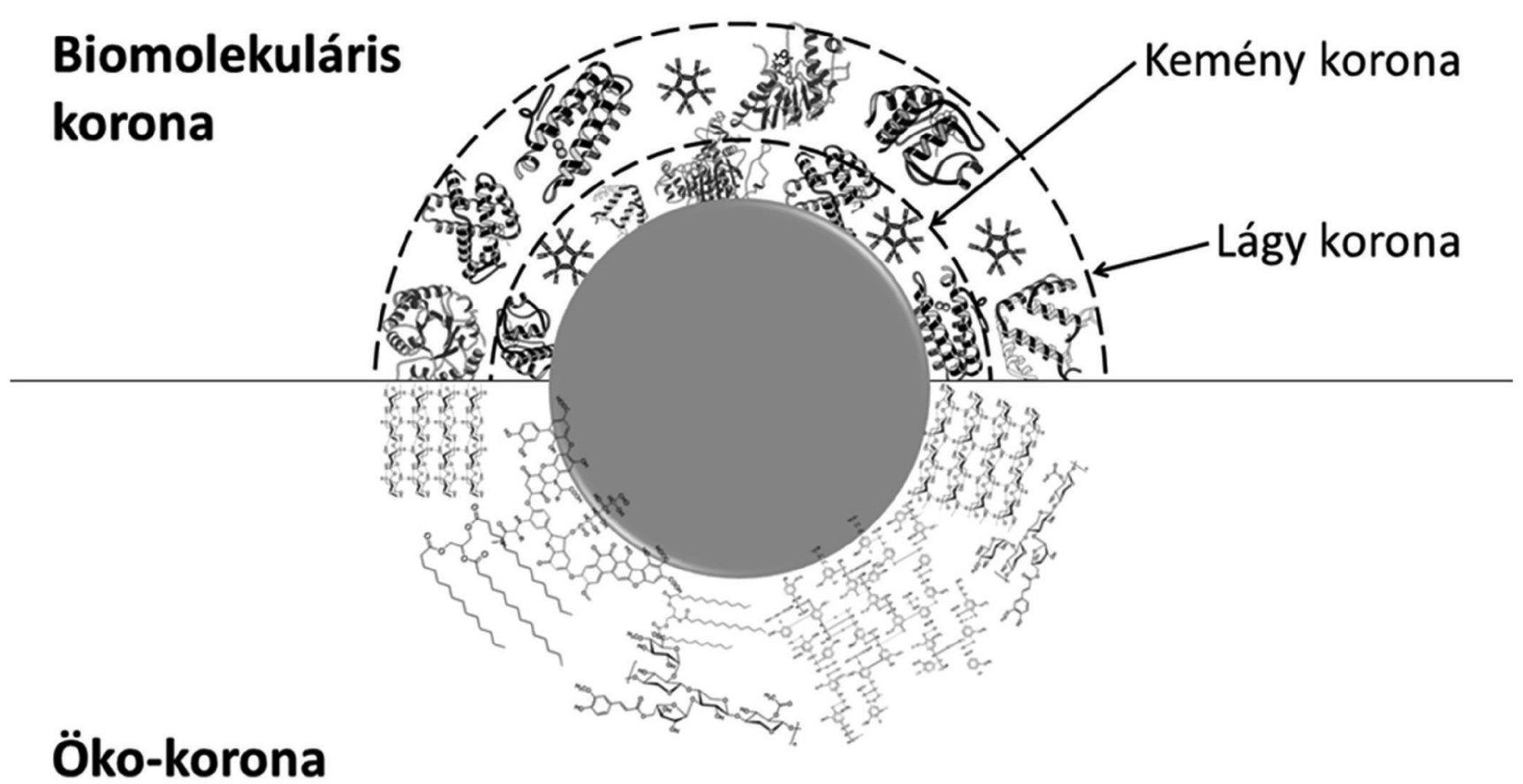

3. Ábra A biomolekuláris korona (fehérjék, lipidek, aminosavak, cukrok, hormonok és metabolitok) és öko-korona (alkotóelemi lehetnek fehérjék, poliszacharodok, zsírok/olajok, nukleinsavak és egyéb szervetlen alapú vegyületek) modellek sematikus ábrája. 
Az eddigiek alapján belátható, hogy a természet nagymértékü diverzitása megannyi lehetőséget kínál a nanoméretü képződmények átformálására. Ezen a területen a legjobban kutatott folyamatok a szulfidizáció, és a már említett kioldódási és (foto)redoxi folyamatok, valamint az aggregáció ${ }^{1,4,24,25}$.

Kutatásaink során mi is vizsgáltuk a természetbe kikerülő nanoanyagok hatását ${ }^{26}, 27$. Egyik tanulmányunkban beszámoltunk a környezeti remediációban leggyakrabban alkalmazott vas nanorészecskék előállítástól függő környezeti hatásáról. Megfigyeltük, hogy a vas szintézis során felhasznált kiindulási vas-sók és redukálószerek nemcsak a kialakult nanorészecske reaktivitását és morfológiáját határozzák meg, hanem befolyásolják a vas részecskék anaerob baktériumokra gyakorolt hatását, azaz a biológiai aktivitását is. Ennek következtében elmondható, hogy a környezeti kármentesítés során a remediáció hatékonyságának fokozása érdekében a megfelelő vas nanorészecske körültekintő kiválasztása javasolt.

Emellett az újabb kutatások rávilágítottak arra, hogy az élő szervezeteknél leírt biomolekuláris korona analógjaként lehetőségünk van definiálni az úgynevezett öko-koronát is. Az öko-koronák túlnyomórészt természetes szerves anyagokból, vagy olyan egyéb szerves és szervetlen vegyületekből épülnek fel, amelyeket a természetben előforduló baktériumok, gombák és algák választanak ki;

\section{Hivatkozások}

1. Klaine, S. J.; Alvarez, P. J. J.; Batley, G. E.; Fernandes, T. F.; Handy, R. D.; Lyon, D. Y.; Mahendra, S.; McLaughlin, M. J.; Lead, J. R., Environ. Toxicol. Chem. 2008, 27 (9), 1825., https://doi.org/10.1897/08-090.1

2. Flynn, H. Nanotechnology Update: Corporations Up Their Spending as Revenues for Nano-Enabled Products Increase; Boston, MA, USA, 2013.

3. Colvin, V. L., Nat. Biotechnol. 2003, 21 (10), 1166-1170., https://doi.org/10.1038/nbt875

4. Nel, A., Science (80-. ). 2006, 311 (5761), 622-627., https://doi.org/10.1126/science.1114397

5. Bakalova, T.; Louda, P., Geophys. Res. Abstr. EGU Gen. Assem. 2014, 16, 2014-6816.

6. Tyshenko, M. G.; Krewski, D.,. Int. J. Nanotechnol. 2008, 5 (1), 143., https://doi.org/10.1016/B978-0-444-62747-6.00010-5

7. Hallock, M. F.; Greenley, P.; DiBerardinis, L.; Kallin, D., J. Chem. Heal. Saf. 2009, 16 (1), 16-23., https://doi.org/10.1016/j.jchas.2008.04.001

8. Ray, P. C.; Yu, H.; Fu, P. P., J. Environ. Sci. Heal. Part C 2009, 27 (1), 1-35., https://doi.org/10.1080/10590500802708267

9. Glover, R. D.; Miller, J. M.; Hutchison, J. E., ACS Nano 2011, 5 (11), 8950-8957., https://doi.org/10.1021/nn2031319

10. Badawy, A. M. El; Luxton, T. P.; Silva, R. G.; Scheckel, K. G.; Suidan, M. T.; Tolaymat, T. M., Environ. Sci. Technol. 2010, 44 (4), 1260-1266., https://doi.org/10.1021/es902240k

11. Gupta, A. Sen., Nanomedicine 2011, 7 (6), 763-779., https://doi.org/10.1016/j.nano.2011.04.001

12. Yacoby, I.; Benhar, Nanomedicine 2008, 3 (3), 329-341., https://doi.org/10.2217/17435889.3.3.329

13. Mirza, A. Z.; Siddiqui, F., Int. Nano Lett. 2014, 4 (1), 94., https://doi.org/10.1007/s40089-014-0094-7

14. Medina-Sánchez, M.; Xu, H.; Schmidt, O. G., Ther. Deliv. 2018, 9 (4), 303-316., https://doi.org/10.4155/tde-2017-0113 ezeket a szakirodalom extracelluláris polimer vegyületekként (EPS) tart számon ${ }^{24}$. Az EPS-ek kémiailag fehérjék, poliszacharodok, zsírok/olajok, nukleinsavak és egyéb szervetlen alapú vegyületek keverékei. Öko-korona alkotó lehet például a cellulóz, hemicellulóz, valamint különböző csersav és huminsav származékok is, amiket Pulido-Reyes és munkatársainak elképzelését folytatva ${ }^{24}$ a 3. ábra is szemléltet, amin a biomolekuláris és öko-koronák összehasonlítása látható.

\section{4. Összefoglalás}

Az irodalmi adatokat és eredményeinket összegezve elmondható, hogy változatos tulajdonságú, specifikus célokra felhasználható nanorészecskék különböző módszerekkel akár ipari méretben is előállíthatóak. Azonban a szintézis körülményei jelentősen befolyásolhatják a nanorészecskék kémiai jellemzőit és biológiai aktivitását, ezért az előállított nanorészecskék fizikai, kémiai és biológiai jellemzőinek teljes körü azonosítása a felhasználás előtt mindenképpen javasolt. Továbbá a környezeti hatások értelmezéséhez elengedhetetlen a környezet és a nanoanyagok között kialakuló speciális határfelületen lejátszódó folyamatok pontosabb megismerése és komplex értelmezése annak érdekében, hogy a megszerzett ismertekből szabályozható, biztonságosan alkalmazható aktív eszközöket és technológiákat formálhassunk.

15. Riviere, J. E.; Scoglio, C. M.; Sahneh, F. D.;

Monteiro-Riviere, N. A., Comput. Sci. Discov. 2013, 6 (1), 014005., https://doi.org/10.1088/1749-4699/6/1/014005

16. Bangham, A. D.; Pethica, B. A.; Seaman, G. V., Biochem. J. 1958, 69 (1), 12-19., https://doi.org/10.1042/bj0690012

17. Vroman, L., Nature 1962, 196 (4853), 476-477., https://doi.org/10.1038/196476a0

18. Hadjidemetriou, M.; Kostarelos, K., Nat. Nanotechnol. 2017, 12 (4), 288-290., https://doi.org/10.1038/nnano.2017.61

19. Lundqvist, M.; Stigler, J.; Elia, G.; Lynch, I.; Cedervall, T.; Dawson, K. A., Proc. Natl. Acad. Sci. U. S. A. 2008, 105 (38), 14265-14270., https://doi.org/10.1073/pnas.0805135105

20. Rónavári, A.; Kovács, D.; Igaz, N.; Vágvölgyi, C.; Boros, I.; Kónya, Z.; Pfeiffer, I.; Kiricsi, M., Int. J. Nanomedicine 2017, Volume 12, 871-883., https://doi.org/10.2147/IJN.S122842

21. Rónavári, A.; Igaz, N.; Gopisetty, M. K.; Szerencsés, B.; Kovács, D.; Papp, C.; Vágvölgyi, C.; Boros, I. M.; Kónya, Z.; Kiricsi, M.; et al., Int. J. Nanomedicine 2018, 13, 695-703., https://doi.org/10.2147/IJN.S152010

22. Karn, B.; Kuiken, T.; Otto, M., Environ. Health Perspect. 2009, 117 (12), 1813-1831., https://doi.org/10.1289/ehp.0900793

23. Linkov, I.; Satterstrom, F. K.; Monica, J. C. J.; Foss, S. Nanotechnol. Law Bus. 2009, 6.

24. Pulido-Reyes, G.; Leganes, F.; Fernández-Pińas, F.; Rosal, R., Environ. Toxicol. Chem. 2017, 36 (12), 3181-3193., https://doi.org/10.1002/etc.3924

25. Lowry, G. V.; Gregory, K. B.; Apte, S. C.; Lead, J. R., Environ. Sci. Technol. 2012, 46 (13), 6893-6899., https://doi.org/10.1021/es300839e

26. Kozma, G.; Rónavári, A.; Kónya, Z.; Kukovecz, Á., ACS Sustain. Chem. Eng. 2016, 4 (1), 291-297., https://doi.org/10.1021/acssuschemeng.5b01185

27. Rónavári, A.; Balázs, M.; Tolmacsov, P.; Molnár, C.; Kiss, I.; Kukovecz, Á.; Kónya, Z., Water Res. 2016, 95 , 165-173., https://doi.org/10.1016/j.watres.2016.03.019 


\section{Nanotechnology in environmental science - the interactions of nanoparticles with the environment}

Nowadays, nanotechnology is one of the most impactful research fields that results in its growing importance in industrial advancements as well; the amount of nanoparticles produced in a year is in the scale of kilotons and their global value is estimated to reach $\$ 4.4$ trillion by the end of $2018^{1,2}$. With the ever-increasing scope and scale of nanoparticle applications it is inevitable for these materials to reach and interact with the environment. The scientific community agrees $^{3-8}$ that due to the unforeseeable consequences of nanotoxicity, more research and if required, even restrictions might be necessary to counteract the possible risks. The task at hand is extremely challenging, since it is not enough to only consider the native properties of certain nanomaterials; the surface interactions between a nanosized object and the surrounding environment offer a variety of different reactions that often result in a completely new and foreign entity from the viewpoint of the environment.

For the sake of this discussion we decided to split the term environment into two distinct categories: living organisms and the nature that surrounds us. The main types of possible surface interactions are illustrated on figure 1, with surface adsorption being the main focus of this work, since it offers the most unique and complex results that affect environmental responses ${ }^{4,10}$.

In the last few decades the interest in nanomedicine has been growing considerably. Many seek the solutions for problems like targeted drug delivery and advanced diagnostic techniques with the tools in the disposal of nanotechnology ${ }^{11-13}$. In order to effectively utilize nanoparticles in this field, we must understand what happens when these materials are administered into the body. The first reports of surface adsorption interactions between proteins and nanoparticles were reported in the $50 \mathrm{~s}$ and $60 \mathrm{~s}^{16,17}$. This relatively simple model has evolved into a quite complex phenomena we now call biomolecular corona ${ }^{18}$. This intricate system is made up of proteins, lipids, amino acids, saccharides hormones and metabolites and gives a sort of biological identity to the novel particles while also affect their aggregation behavior, thus their pharmacokinetics ${ }^{15}$.

Recently, interactions between several metal nanoparticles and living organisms have been investigated at the
Department of Applied and Environmental Chemistry at the University of Szeged. The aims of our work were to develop environmentally benign methods for the preparation of silver nanoparticles, coupled with their in-depth characterization, as well as to analyze their behavior and their overall effects on chemical and biological systems. We successfully produced silver nanoparticles using Phaffia Rhodozyma, coffee and green tea extracts; moreover, based on our comprehensive screening, we delineated major differences in the biological activity of our samples.

As for nature, similar processes must be understood in order to best utilize them in remediation purposes, but also to fully understand their possibly hazardous properties that could result in ground, water or air contaminations ${ }^{22,23}$. During our research, we also investigated the effects of naturally occurring nanomaterials ${ }^{26,27}$. In one of our studies, we reported about the synthesis dependent environmental impact of iron nanoparticles most often used in environmental remediation.

In the light of recent publications ${ }^{24}$ an interesting new approach has been proposed. Since extracellular polymeric substances (EPS) secreted by microbes can act similarly to biomolecules in living organisms, a model of the so called eco-corona can be described analogous to the biomolecular corona approach that has been described earlier. This advance can lead to interesting new perspectives and a newfound understanding of the behavior of nanomaterials in nature.

Concluding the current state of the literature with our own findings, it can be stated that the eco-friendly, green synthesis of nanoparticles can be realized even on the industrial scale. However, the circumstances of preparation method significantly modify the activity of the obtained nanoparticles in living systems, a thorough characterization of their physical, chemical and biological properties must mandatorily precede their large-scale applications. Furthermore, in order to create new, controllable and safe tools and technologies it is essential to fully understand the environmental effects, and that means we must utilize our acquired knowledge in investigating and explaining the interactions on the special surface between nanomaterials and their environment. 